\title{
Interdisciplinary high-school curriculum in electro-optics as a tool to enhance students' interest in optics and electronics
}

\section{Aharon Gero, Efrat Zach}

Aharon Gero, Efrat Zach, "Interdisciplinary high-school curriculum in electrooptics as a tool to enhance students' interest in optics and electronics," Proc. SPIE 9289, 12th Education and Training in Optics and Photonics Conference, 92890L (17 July 2014); doi: 10.1117/12.2070379

SPIE Event: 12th Education and Training in Optics and Photonics Conference, 2013, Porto, Portugal 


\title{
Interdisciplinary High-School Curriculum in Electro-optics as a Tool to Enhance Students' Interest in Optics and Electronics
}

\author{
Aharon Gero, Efrat Zach \\ Department of Education in Technology and Science, \\ Technion - Israel Institute of Technology, Haifa 32000, Israel
}

\begin{abstract}
An interdisciplinary curriculum in electro-optics was recently developed and implemented in a leading high school. This unique three-year program integrates optics and electronics and is designed to enhance students' interest in these areas. The study described here characterized the changes during the course of the school year in the attitudes towards the program and towards future pursuit of physics and engineering of fourteen $12^{\text {th }}$ grade students. Questionnaires and semistructured interviews were used to collect data. Research findings reveal a considerable improvement in students' attitudes towards interdisciplinary studying of optics and electronics. The research also indicates that in addition to an increase in the students' interest in the program, their desire to continue with more advanced studies in these fields increased as well.
\end{abstract}

Keywords: Optics education at high school, interdisciplinary curriculum, students' attitudes towards optics

\section{INTRODUCTION}

An interdisciplinary curriculum in electro-optics was recently developed and implemented in a leading Israeli high school. This three-year program integrates optics and electronics and is designed to enhance students' interest in these areas. The program begins in $10^{\text {th }}$ grade with the fundamentals of optics and electronics. In $11^{\text {th }}$ grade, the students study the basics of electro-optics, and during the final year of study $\left(12^{\text {th }}\right.$ grade), the program focuses on electro-optical systems. Like other interdisciplinary high-school curricula (e.g. in robotics ${ }^{1}$, nantotechnology ${ }^{2}$ or information technology ${ }^{3}$ ), this program integrates engineering principles into science teaching with the objective of enhancing the students' interest in these subjects and encouraging them to develop future careers in these areas.

The research described here characterized the attitudes of students in the final phase of the program towards interdisciplinary learning of optics and electronics and towards future pursuit of physics and engineering. The authors chose to focus on $12^{\text {th }}$ graders since the interdisciplinary component at this phase of the program, which deals with electro-optical systems, is the most significant compared with other stages of the program $\left(10^{\text {th }}\right.$ and $11^{\text {th }}$ grades $)$.

\section{INTERDISCIPLINARY EDUCATION}

Interdisciplinarity is the cooperation between experts from different disciplines in order to create interaction between the disciplines or reorganize concepts and methodologies taken from the said disciplines ${ }^{4}$. Lattuca et al. ${ }^{5}$ distinguish between four levels of interdisciplinarity:

- Informed disciplinarity, in which emphasis is on a single discipline using other disciplines to shed light on specific aspects of the said discipline;

- Synthetic interdisciplinarity, in which concepts and theories from different disciplines are combined in a way that enables to identify each concept or theory with its source discipline;

- Transdisciplinarity, in which concepts and theories from different disciplines are combined in a way that does not enable to identify each concept or theory with a specific discipline;

12th Education and Training in Optics and Photonics Conference, edited by

Manuel F. P. C. Martins Costa, Mourad Zghal, Proc. of SPIE Vol. 9289, 92890L

(C) 2014 SPIE, OSA, IEEE, ICO · doi: 10.1117/12.2070379

Proc. of SPIE Vol. 9289 92890L-1 
- Conceptual interdisciplinarity, in which disciplinary perspectives are combined without requiring a solid disciplinary basis.

Since interdisciplinary learning provides students with more opportunities to relate new knowledge to previously acquired knowledge, according to Piaget's theory of cognitive development, such learning should be more effective compared to disciplinary learning. Additionally, interdisciplinary learning is expected to enhance students' interest ${ }^{5}$. According to literature, interdisciplinary high-school curricula in robotics ${ }^{1}$ and geospatial technology ${ }^{6}$ led to an improvement in students' attitudes toward these disciplines. Moreover, the students' desire to pursue more advanced studies in engineering increased as well ${ }^{7}$.

At the same time, interdisciplinary teaching poses unique challenges ${ }^{8}$. The teacher should contend with teaching a discipline he/she was not trained to teach. In addition, the teacher should carefully balance the interdisciplinary and disciplinary components in order to avoid shallow treatment of the disciplinary content.

\section{THE PROGRAM}

The program begins in $10^{\text {th }}$ grade with the fundamentals of geometrical optics and basic concepts in electricity (Ohm's law and Kirchhoff's laws) and electronics (sinusoidal signals and operational amplifiers). In $11^{\text {th }}$ grade, the students study wave optics, the dual nature of light, atomic structure, light-matter interactions, and fundamentals of modulation $(\mathrm{AM} / \mathrm{FM})$. During the final year of study $\left(12^{\text {th }}\right.$ grade), the program focuses on light sources (LED and laser), radiation detectors (photodiodes and solar cells), and electro-optical systems such as optical communication systems. In this phase the students execute a final project of designing and implementing an electro-optical system. Studies include theoretical lessons and practical lessons that take place in the laboratory and in simulation environments such as MATLAB.

The first two years of the program can be classified as synthetic interdisciplinary phases, while the final year is a transdisciplinary stage, characterized by a higher level of interdisciplinarity. In light of the challenges of developing interdisciplinary curricula, discussed above, emphasis was placed on achieving a balance between the interdisciplinary and disciplinary components of the program, as can be seen in Table 1. In addition, to ensure mastery of the various disciplines, all of the program's teachers have advanced degrees in physics and electrical engineering.

\section{RESEARCH GOAL AND METHODOLOGY}

The research goal was to track changes, which took place during the final phase of the program, in students' attitudes towards interdisciplinary learning of optics and electronics and towards future pursuit of physics and engineering.

The research population consisted of fourteen $12^{\text {th }}$ grade students who in 2012 participated in the final phase of the electro-optics program (after successfully completing the two preceding phases). It is important to note that the students had not been exposed to interdisciplinary teaching prior to participating in this program. The students were asked to complete an anonymous questionnaire both at the beginning of the academic year and at its end. In addition, with the objective of completing the information gained through the questionnaires, six semi-structured interviews were held with students at the end of the school year.

The questionnaire comprised two parts. The first part consisted of open-end questions about the students' reason for participating in the program (e.g. "Why are you participating in the program?") and about their attitudes towards advanced studies (e.g. "Do you want to go to university in the future? If so, what do you want to study?"). The second part was a binary questionnaire that consisted of six pairs of statements expressing attitudes towards interdisciplinary learning of optics and electronics as manifested in the program. For each pair of statements, the students were requested to indicate which best expressed his or her attitude. For instance, in the following statement pair, Statement (a) expresses a positive attitude toward the interdisciplinary program: "(a) The combination, in the electro-optics program, of optics and electronics is interesting because it enables me to view the study material from different viewpoints; (b) The combination, in the electro-optics program, of optics and electronics is boring because it leads to repetition of the same topics". On the other hand, in the following example, Statement (b) expresses a positive attitude towards the program: "(a) The combination, in the electro-optics program, of optics and electronics leads to superficial learning of both optics 
and electronics; (b) The combination, in the electro-optics program, of optics and electronics leads to deep understanding of both optics and electronics." All statements were validated by two engineering education experts.

Table 1. Curriculum of the electro-optics program.

\begin{tabular}{|c|c|c|}
\hline Academic Year & Topic & Description \\
\hline $10^{\text {th }}$ grade & $\begin{array}{l}\text { Introductory } \\
\text { studies }\end{array}$ & $\begin{array}{l}\text { a. Geometrical optics }(24 \mathrm{~h}) \text { : Reflection law, } \\
\text { refraction law, total internal reflection, mirrors, } \\
\text { lenses, the eye, camera, telescope, microscope } \\
\text { b. Electricity }(6 \mathrm{~h}) \text { : Electrical current, electrical } \\
\text { voltage, electrical resistance, Ohm's law, } \\
\text { equivalent resistance, Kirchhoff's laws } \\
\text { c. Electronic components and systems }(12 \mathrm{~h}) \text { : } \\
\text { Sinusoidal signals, operational amplifiers }\end{array}$ \\
\hline $11^{\text {th }}$ grade & $\begin{array}{l}\text { Introduction to } \\
\text { electro-optics }\end{array}$ & $\begin{array}{l}\text { a. Electromagnetic waves and the electromagnetic } \\
\text { spectrum }(7 \mathrm{~h})^{*} \\
\text { b. Wave optics }(12 \mathrm{~h}) \text { : Interference, diffraction, } \\
\text { dispersion and polarization } \\
\text { c. The dual nature of light }(2 \mathrm{~h}) \text { : The photoelectric } \\
\text { effect } \\
\text { d. Atomic structure }(2 \mathrm{~h}) \text { : Energy levels and Franck- } \\
\text { Hertz experiment } \\
\text { e. Light-matter interactions }(2 \mathrm{~h}) \text { : Absorption, } \\
\text { spontaneous emission and stimulated emission } \\
\text { f. Fundamentals of modulation }(18 \mathrm{~h}):{\mathrm{AM} / \mathrm{FM}^{* *}}^{*}\end{array}$ \\
\hline $12^{\text {th }}$ grade & $\begin{array}{l}\text { Electro-optical } \\
\text { systems }\end{array}$ & $\begin{array}{l}\text { a. Optical fibers }(15 \mathrm{~h}): \text { Structure and principle of } \\
\text { operation, applications } \\
\text { b. Light sources in optical communication }(15 \mathrm{~h}) \text { : } \\
\text { LED, laser }{ }^{* * *} \\
\text { c. Radiation detectors }(15 \mathrm{~h}) \text { : Detector } \\
\text { characteristics, noise sources, photodiodes, solar } \\
\text { cells } \\
\text { d. Optical communication systems }(30 \mathrm{~h}): \text { Structure } \\
\text { and principle of operation, applications } \\
\text { e. Final project }(180 \mathrm{~h})^{* * *}\end{array}$ \\
\hline
\end{tabular}

"Disciplinary component (Optics/Physics)

${ }_{* * *}^{*}$ Disciplinary component (Electronics)

${ }^{* * *}$ Interdisciplinary component

\section{FINDINGS}

Figure 1 presents the mean attitude score (ranging between 0 and 10) on the binary pretest, completed at the beginning of the school year and on the posttest, completed at its end. It is evident that students' attitude towards interdisciplinary learning of optics and electronics improved considerably. Cohen's d was found equal to 0.67 , indicating medium-high level of effect size. 
Following are some excerpts from interviews, in which students were asked "What do you think about the combination in the program of optics and electronics?". The excerpts expose the students' positive attitude towards integrating optics and electronics. Students found the integration of the two areas to be interesting:

"It's interesting that it [optics and electronics] eventually integrates... you see how it all comes together... all the things that in $10^{\text {th }}$ grade cause you to ask why".

Moreover, students believed that the integration leads to a deeper learning of the disciplinary contents:

"The integration helped... Thanks to it, our learning of electronics was more in-depth".

An analysis of the students' answers to the open questionnaire supports the above finding. In response to the question "Why are you participating in the program?", 57\% of pretest respondents answered that they were participating out of interest, while $14 \%$ gave a utilitarian reason, and wrote that they were participating in order to receive a higher quality matriculation certificate that would be of use to them in the future (the rest of the students mentioned miscellaneous reasons, such as timetable constraints or fulfilling the expectations of family). In response to the same question on the posttest, $79 \%$ of respondents indicated interest and only $7 \%$ mentioned the utilitarian reason.

In response to the question "Do you want to go to university in the future? If so, what do you want to study?", $71 \%$ of pretest respondents mentioned physics or engineering, $21 \%$ wrote that they want to study other subjects and the rest of the students wrote that they do not intend to study at university. In response to the same question on the posttest, $86 \%$ mentioned physics or engineering studies and only $7 \%$ wrote they would like to study other subjects. The rest $7 \%$ wrote that they are not interested in higher education.

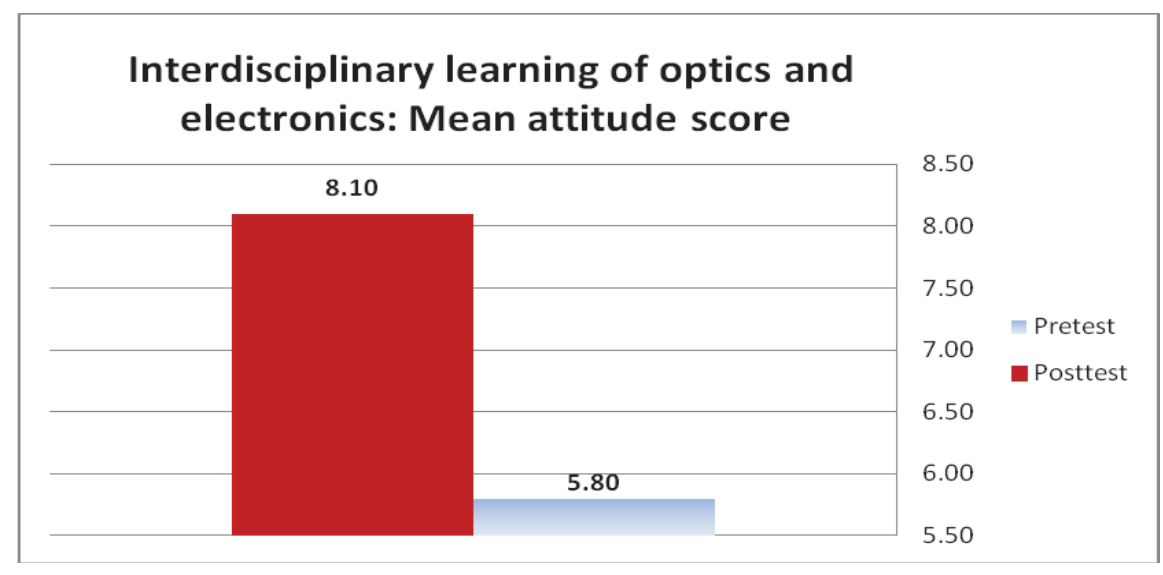

Figure 1. Interdisciplinary learning of optics and electronics: Mean attitude score.

\section{DISCUSSION}

The improvement observed over the course of the year in students' attitude towards interdisciplinary learning of optics and electronics was also manifested in their reasons for participating in the program. A comparison between posttest responses and pretest responses reveals that the weight of interest (intrinsic motivation) as a reason for participating in the program increased at the expense of utilitarian reasons, such as receiving a higher quality matriculation certificate (extrinsic motivation/identified regulation). This is significant in light of the self-determination theory ${ }^{9}$, which attributes special importance to intrinsic factors in increasing motivation levels. The research also showed that over the course of the year, the students' desire to pursue more advanced studies in the area increased. These findings are in line with those of other studies on interdisciplinary high-school curricula in robotics ${ }^{7}$ and aviation ${ }^{10}$. 


\section{SUMMARY}

The paper presented a three-year curriculum in electro-optics that integrates optics and electronics. The research described here characterized the attitudes towards interdisciplinary learning of optics and electronics and towards future pursuit of physics and engineering of students who were in the final phase of the program. The findings reveal a notable improvement in students' attitudes towards interdisciplinary learning of optics and electronics over the course of the year. Students found the integration of the two areas to be interesting and believed that it leads to a deeper learning of the disciplinary contents. The research also indicates that in addition to an increase in the students' interest in the program, their desire to continue with more advanced studies in these fields increased as well.

\section{ACKNOWLEDGEMENTS}

The authors would like to thank Naftali Even-Haim for his cooperation and contribution.

\section{REFERENCES}

[1] Rockland, R., Bloom, D. S., Carpinelli, J., Burr-Alexander, L., Hirsch, L. S. and Kimmel, H., "Advancing the "E" in K-12 STEM education," J. Technol. Stud., 36, 53-64, (2010).

[2] Orgill, M. and Crippen, K. J., "What's so big about being small? The interdisciplinary opportunity nanoscience," The Science Teacher, 76, 41-48 (2009).

[3] Rursch, J. A., Luse, A. and Jacobson, D., "IT-Adventures: A program to spark IT interest in high school students using inquiry-based learning with cyber defense, game design, and robotics," IEEE Trans. Educ., 53, 71-79 (2010).

[4] Apostel, L., Berger, G., Briggs, A. and Michaud, G., [Interdisciplinarity: Problems of Teaching and Research in Universities], OECD, Paris, 127-139 (1972).

[5] Lattuca, L. R., Voight, L. J. and Fath, K. Q.,"Does interdisciplinarity promote learning? Theoretical support and researchable questions," Rev. High. Educ., 28, 23-48 (2004).

[6] Nugent, G., Barker, B., Grandgenett, N. and Adamchuk, V. I., "Impact of robotics and geospatial technology interventions on youth STEM learning and attitudes," J. Res. Technol. Educ., 42, 391-408 (2010).

[7] Brand, B., Collver, M. and Kasarda, M., "Motivating students with robotics," The Science Teacher, 75, 44-49 (2008).

[8] McComas, W. and Wang, H., "Blended Science: The rewards and challenges of integrating the science disciplines for instruction," School Science and Mathematics, 98, 340-348 (1998).

[9] Deci, E. L., and Ryan, R. M., "The 'what' and 'why' of goal pursuits: Human needs and the self-determination of behavior," Psychol. Inq., 11, 227-268 (2000).

[10] Gero, A., "Enhancing aviation high school students' interest in physics and engineering: An interdisciplinary program on aviation weapon systems," Proc. $2^{\text {nd }}$ Int. Conf. STEM Educ., 28-32 (2012). 